\title{
Political and event ecology: critiques and opportunities for collaboration
}

\author{
Rodrigo Penna-Firme ${ }^{1}$ \\ Pontifícia Universidade Católica do Rio de Janeiro, Brazil
}

\section{1. "Against political ecology": the rebirth and development of event ecology}

Political ecology has faced two main critiques throughout its recent development. In a very influential article, "Against political ecology," Andrew Vayda and Bradley Walters (1999) argued that political ecologists were making a priori assumptions about the linkages between local environmental change and national and global political economic systems. The second critique has been that there is no need for the term "ecology" in political ecology, since research in the field had only indirectly focused on ecology and environmental changes.

According to Vayda and Walters (1999: 268), human-environment interactions can be explained by "placing them within progressively wider and or denser contexts." They propose "event ecology" as a research method to be carried out by following two basic steps: "... begin research with focus on the environmental event [which they equate with environmental change] that one wants to explain and then work backward in time and outward in space so as to construct chains of causes and effects leading to those events and changes" (Vayda and Walters 1999: 169, emphasis added). They explain that one of the greatest advantages of using event ecology in human-environment research is that it encourages researchers to use whatever method and theory best suit the research questions, without having to follow any prescribed disciplinary and programmatic imperative. They argue that no a priori unit of analysis, like the 'ecosystem' or the 'watershed', is needed.

Yet, the history of these ideas does not end here. Walters and Vayda, in "Event ecology, causal historical analysis, and human-environment research" (2009) reformulated what they called the "limited rationale" of their own previous event ecology approach. They addressed critiques of event ecology and made substantial and relevant changes. They incorporated, for instance, the construction of causal histories of interrelated social and biophysical events through a process called abduction-eliminative inference and reasoning from effects and causes. This basic and ingenious idea adapted counterfactual analysis for use in their event ecology. As they explain it, counterfactual reasoning comes into play to ascertain whether or not the presence of a particular antecedent event had causal influence over the event under scrutiny. To solve this puzzle, the following question should be asked: If this antecedent factor or event were absent, would the event of interest have turned out the same? Walters and Vayda say that where the answer is negative, such an event or factor has causal importance (2009: 541).

In sum, what Walters and Vayda propose is a stepping-stone methodology to advance research concerned with understanding the driving forces of environmental change, one that is empirically and inductively driven, instead of a priori assuming general causes of change. According to them, "theory-driven research" involves studies that are testing theories and hypotheses previously established (a priori), and this style of reasoning tends to dismiss empirical and problem-oriented approaches.

In this article, I discuss the origins and progress of event ecology and demonstrate its strengths and limitations vis-à-vis the development of political ecology research. Drawing on the case of a recently recognized quilombola community within a nature conservation unit in the State of São Paulo, Brazil, I propose a collaborative event ecology that combines the rationale of event ecology with critical perspectives inspired by political ecology's focus on power relations, conservation, and justice. This article is divided into 11 sections. Section 2 reconstructs the history of event ecology with its epistemological strengths and limitations. Then the article focuses on the rise of quilombos in Brazil and the challenge of reconciling the presence of traditional groups within nature-protected areas. After describing the biophysical, human, and institutional settings where the study was conducted, I move to a critique of the application of wilderness perspectives for nature conservation in Brazil, more specifically to the Atlantic Forest biome. In section 7, drawing on ethnographic data, I lay out the approach I propose to complement and modify event ecology. Inspired by conversations on environmental justice perspectives, I demonstrate that what is nature conservation for some may signify oppression, cultural loss, and negative livelihood changes for others.

\footnotetext{
${ }^{1}$ Dr. Rodrigo Penna-Firme, Assistant Professor, Department of Geography, Pontifícia Universidade Católica do Rio de Janeiro (PUC-Rio), Brazil. Email: rodrigopennafirme "at" puc-rio.br. I am grateful for reviews by Eduardo S. Brondízio and Joanna T. Broderick. I would like to thank the local people of Camorcy who allowed me to conduct this research. I acknowledge a year-long Grassroots Development Fellowship from the Inter-American Foundation (IAF) and the Institute for International Education (IIE) to conduct fieldwork in Brazil from 2008 to 2009. This paper was winner of the Eric Wolf Prize, Political Ecology Society, 2012, and appears in a JPE Special Section of Eric Wolf Prize papers edited by Casey Walsh.
} 
Section 8 uses ethnographic evidence to further illustrate how a quilombola identity is being constructed in Camorcy vis-à-vis the development of ethnic tourism and ideas for conservation. Then, in the next section, I analyze local people's narratives, perceptions, and choices of meaningful events and contrast them to research-oriented choices of events based on the framework of event ecology. Section 10 focuses on the interplay between multicultural and conservation policies in Brazil to illustrate how these interactions are altering ideas of nature, human rights, and development. The article concludes by drawing broad lessons from the case study. I argue that seeing 'events' other than research-oriented ones may help us better understand why some places achieve conservation while others do not. I suggest that a collaborative event ecology may perform the dual tasks of exploring the historical environmental changes and their causes as well as assessing the local-level social impacts and meanings of conservation and degradation for diverse stakeholders. I also contend that a collaborative methodology should include multiple stakeholders' understandings of what is perceived as good and bad, and for whom.

\section{Some potential pitfalls of event ecology and reconstruction of its trajectory}

These discussions of methodology and political ecology are to some extent an outgrowth of Vayda's earlier idea of "progressive contextualization" as a method for human ecology (Vayda 1983). His work was seen as a major contribution to the development of problem-oriented research methods, rationally and empirically allowing one to progressively and cautiously identify connections between apparently disparate socioeconomic and environmental phenomena across time and space. In the 1980s, other scholars were developing similar approaches toward human-environment relations named "the ecology of cumulative change" (Lees and Bates 1990). These approaches marked a transition in environmental anthropology from a focus on the use of the ecosystem as the main unit of analysis (Moran 1990) to a renewed processual phase, where emphasis was (and still is) placed on how individuals and groups respond and adapt to environmental change, shaped by institutions and cultures (Little 1999).

The idea of progressive contextualization proposed by Vayda (1983) has fostered scholarly understanding of environmental changes in new ways. Political ecologists have consciously or subconsciously attempted to incorporate these insights into research by moving from chains of explanation to a web of relationships, and from a priori assumptions to multidimensional, grounded approaches. Critics of event ecology and progressive contextualization have argued that the method does little to unveil the deepest political roots of environmental problems. Robbins (2004) contends that the wider or denser the contexts, the poorer and scarcer the political questions become (or they are completely absent or misguided). Research based on event ecology alone may not capture, for instance, power relationships in the state apparatus (policies, the police force, courts, media, and so-forth), in local entrepreneurs' activities, or the roots of land degradation by widening scales of analysis and moving backward in time. There is a need for more than shifting scales and a historical perspective.

Other political ecologists have made similar critiques. Karl Zimmerer for instance declares that:

...experts in biogeophysical and social sciences make assumptions and adopt frameworks about scale that guide the elaboration of the multiplying number of models and publicized reasoning about human-induced environmental change. The scale features of scientific models are reflective of the cause-effect relations that are contained at the core of these models. Similarly, the assumptions and frameworks regarding scale in these models are typically used to guide or target the increasing number of policy prescriptions and projects that are informed through environmental science. As a result, the assumption and reasoning about scale are often replete with a variety of political implications - and thus a politics of science. (Zimmerer 2006:16)

A second critique of Vayda and Walters' claim about the supposed lack of ecology in political ecology (1999) is more easily unpacked, and for a simpler reason. Nature, environmental change, and socioeconomic success mean different things to different people. More specifically, this critique reinforces the idea that choosing events in historical environmental change research is also "a matter of taste." According to critics, environmental change may be positive for some purposes and for some peoples, while being negative for other stakeholders or in meeting other objectives. Paul Stern et al. (2002) explain that the research tradition that examines common-pool resources begun with questioning the sustainability of resource use. Sustainability remains an important question, but it is not the only one for resource users. For them, livelihoods and well-being are often more important than the status of a particular resource or commodity. Stern et al. also say that; 
...researchers who want to produce knowledge of practical value need to identify and examine the full range of outcome conditions that matter to the people who use, manage, and/or depend on the resource being studied. It is these people whose decisions the research will inform and who face important tradeoffs. Sometimes, one desirable outcome (i.e., sustainability or equity) can be achieved only by sacrificing another (i.e., economic efficiency). Institutions may be judged by how well they provide jobs and wealth, maintain good social relations in a community, provide access to resources from outside, and many other criteria in addition to resource sustainability. Research that ignores the multiplicity of valued outcomes is unlikely to produce realistic models for real decisions, which must take into account those varied outcomes. (Stern et al. 2002:457)

It seems reasonable to say that preconceived models, methods, and world views (about nature or not) are inevitable, oftentimes contradictory and problematic. This brings us to another major epistemological paradox. On one hand, one cannot frame and understand any problem (i.e., environmental degradation/conservation, changes in livelihoods, and so on) without using a priori concepts, world views, and specific classification systems (all manifested through language). On the other hand, the use of preconceived world views to address problems affecting local people's livelihoods (the etic approach) does not necessarily reflect or address local people's own demands, expectations, problems, solutions, life histories, and livelihoods (the emic approach). I believe that adopting a modified version of event ecology may help overcome some of these practical and epistemological difficulties.

Scholars have demonstrated that views of resource management and the environment can reproduce historical social biases. Açaí, an Amazonian palm tree fruit (sold as a berry in Europe and the United States), was once a regional staple and has now become an international fashion food. Eduardo Brondízio (2008) demonstrates that government policies have perceived caboclos (the Amazon local population) as backward forest gatherers (extrativistas), and the forested region they inhabit as unmanaged. Through ethnographic, historical, and land-use/cover change analyses, he has instead argued that caboclos are forest farmers who have intentionally managed and maintained large tracts of the Amazon forest under intensive açaí agroforestry systems. For incautious observers, an aerial image may present an homogeneous and intact tract of forest, when in reality it is a mosaic landscape, the result of intensive historical use and management of forest resources by these populations. Brondízio (2008) also explains that seeing caboclos as extrativistas reproduces a past narrative that traps them into a cycle of socioeconomic and cultural invisibility. As a result, this social group is not given access to agricultural credit and not included in other government policies. Ultimately, Brondízio argues that based on biased and preconceived images of these people, the landscape they have inhabited and managed for centuries may end up being misinterpreted. For instance, government agencies and conservation NGOs see the region as an intact and pristine environment, whereas in reality, when seen through the eyes of local individuals and communities, the region provides completely distinct meanings, histories, socioeconomic utility, and interpretations of ecology.

Another example of conflicting views of nature is the study conducted by Robbins (2003a,b). Comparing land-cover categories of local groups and the forestry service in the Indian state of Rajasthan, he demonstrates that land categories are more a reflection of the political interests of the categorizer than a mirror of the actual biophysical features of the landscape. In sum, even objective landscape features are subjected to varying interpretations depending on where, when, and mostly by whom the classification is made.

Vayda and Walters propose that in conducting research into the causes and history of environmental change, the goal should be to "strive to minimize ... antecedent theory or disciplinary bias ... where subjective judgments are most clear" (Walters and Vayda 2009:544). Although this is undeniable, I argue that in order to do so, one should initiate research by first scrutinizing the reality on the ground, based on a combination of the researcher's position and the views of the people most directly affected by whatever event is at stake. This is the importance of incorporating empirical research in political ecology: a combination of a researcher's observations and questionnaires, for instance, allows him/her to grasp what is going on behind the scenes, on the ground, face-to-face, and through daily life interactions with locals and other interest groups. However, assuming that one could begin research free from antecedent bias is to conceive this person as tabula rasa (having no innate or previous ideas and concepts). The best one can achieve is to put him/herself in other people's shoes for a while (an emic approach), which requires a large dose of intellectual humbleness to set aside previous academic training and life experience. Events, for that matter, are chosen according to researchers' a priori and "built-in" frames of perception. For instance, biologists may tend to overlook poverty, whereas a sociologist could miss on-the-ground connections between poverty and natural resource quality, quantity, access, and control.

\section{Quilombos in nature-protected areas}

Since the Brazilian Constitution of 1988, many rural communities in the country have been granted land rights based on their ethnicity, settlement history, and Afro-Brazilian ancestry (French 2009; Gomes 2003). For some communities, the immediate result of these changes has been a complex process of internal 
rethinking of identity, values, and social practices to conform to the opportunities opened by a legally endowed quilombola identity, and thus, rights to land. ${ }^{2}$ Additionally, in 2001, the Brazilian Congress passed the National System of Conservation Units (SNUC) Law providing a framework for the establishment of protected areas that can include the presence of traditional populations, a category that can include quilombolas and caiçaras, ${ }^{3}$ among other ethnic groups (Medeiros 2006). The underlying assumption, however, is that ecotourism, low-intensity subsistence practices, and management of non-timber forest products will create revenues and foster positive links between local communities and nature conservation.

I contend that because of increasing nationalization and globalization of nature conservation and ecotourism, new forms of commodification of intangible goods such as the performance of local and regional identities are emerging. Furthermore, this process sets the stage for communities to negotiate internal and external access to resources, economic opportunities, and land rights. I argue that the foremost challenge for these communities is to find a balance between negotiating their own identities, their economic aspirations, and the expectations created by legal, cultural, and environmental discourses. The same source of social capital built through the intersection of ethnic and environmental alliances might either threaten or empower them. On one hand, quilombola communities have gained an opportunity as a traditional population to be associated with the environmental movement while subsuming their historical stigmas (e.g., black poor and rural poor) within an image of indigeneity. On the other hand, this hybrid identity may imply that they are ecologically adapted, but culturally, economically, and demographically frozen in time: a repackaged version of the "noble savage" (Redford 1990). As a result, while many quilombola communities living within parks of high conservation value might benefit from being transformed into traditional populations, they risk being kept under economic constraints, since traditional populations are not expected to develop strong market links and high rates of consumption; in other words, they are not expected to change the material conditions which attest, as cultural markers, to their identity.

I call this paradox a commodification of poverty, given that the goal of nature protection schemes can contribute to maintaining traditional populations with limited capacity for adapting to and dealing with new economic demands and opportunities - and intergenerational demographic changes. Through this case study, I examine to what extent policies aiming at social and environmental problems should confront poverty as a major issue underlying most human-environment relations, and the goals of nature conservation.

Karl Offen (2003) provides an explanation for the connection between ongoing ethnic-based land reforms and the expansion of nature-conservation territories (biological corridors in Colombia) and parks in Latin America initiated in the 1990s. He argues that the encounter between external macro-forces represented by top-down pressures and demands from multi- and bilateral development organizations such as the World Bank (the major lender for the land demarcation and titling for black communities in Latin America) and bottom-up "new" social movements based on indigenous rights, gender, ethnicity, and environmental justice rather than class (Alvarez et al. 1998) are not a coincidence, but rather a remarkable strategy to control peoples and territories.

Offen asks why there is a convergence of interest around the issue of biodiversity protection and the rights of indigenous groups and black territories between policies and historically antagonistic entities. The short answer, he suggests, is that "various groups have mobilized to ensure that their interests receive attention within global environmental and indigenous agendas" (2003:48). The longer answer has three main elements. The first is the perception by global institutions that indigenous groups and local people possess crucial ecological and practical knowledge about the environments they inhabit. The second is the understanding that the protection of these peoples' environments without local participation is likely to fail. The third element is that the decentralization of state duties and its transfer to local-level administrations has been central to state reforms in Latin America.

Finally, Offen (2003:51) contends, "the World Bank views collective titles as necessary to stabilize property regimes in developing countries, to remove biodiversity lands from the vagaries of market forces (by insuring that collective properties cannot be transferred), to foment foreign direct investments, and to attract appropriate technologies to biodiversity areas." In Brazil, some indigenous groups are starting to engage in carbon trade negotiations directly with international corporations outside state regulations and influence. To illustrate, the Irish company Celestial Green has bought all rights to carbon credits from the

\footnotetext{
${ }^{2}$ Quilombolas are African-diaspora communities in Brazil formed mainly by runaway slaves in the 19th century and former slaves after the end of slavery in 1888. After two decades of military dictatorship, Brazil's Constitution of 1988, which is a landmark in the process of (re)democratization, incorporated many special concessions and civil rights including a clause granting land rights to communities of descendants of runaway slaves, known as quilombos. This provision states that survivors of Afro-descendants occupying their lands are recognized as definitive owners, and the State shall issue titles to the land (French 2006 and 2009; Gomes 2003). In 2003, a presidential decree asserted that the main criterion to define who belongs to quilombola communities was self-identification. Since the quilombo decree was passed, hundreds of communities have claimed communal territorial rights based on Afro-Brazilian cultural markers linked to a quilombola ethnic identity.

${ }^{3}$ Caiçara refers to fishing and agricultural communities in southeastern Brazil with strong ties to the local environment, where European, indigenous, and African ancestry are blended and hard to distinguish (Hanazaki et al. 2000).
} 
indigenous community Munduruku in Pará for US\$120 million, as well as other benefits to be achieved with the commercial exploration of biodiversity found in 2.3 million hectares of the community's land. ${ }^{4}$

Other critics have pointed out that the "territorial turn" (Offen 2003) made on behalf of black communities in Latin America has been achieved under a climate of paternalism in which residents are provided with limited control of the resources and their territory in exchange for their commitment to conserve nature (Hoekema and Assies 2000). I ask whether these arguments apply to the case of the quilombo of Camorcy and other local and rural communities recognized as traditional people whose territories overlap and/or surround hot spots of biodiversity in Brazil. If so, what are the cultural, economic, and environmental effects? The case of Camorcy further illustrates the local impacts of wider forces that have promoted territorial land titling of collective land to black communities in Latin America, along with a wave of multicultural policies that recognize ethnic-based rights, enacted through constitutional reforms in various countries in the region (Anderson 2007; French 2009; Sánchez 2008; Wade 1995).

\section{Study site}

Camorcy was chosen as the focal community because it illustrates a situation of poverty in an area rich in resources and potential. On one hand, a lush tropical green forest, crystalline fresh water sources, and a white-sand beach are available. On the other hand, the low socioeconomic conditions among its people are pervasive. Camorcy offers a unique opportunity to assess some of the combined impacts of conservation and multicultural policies on the ground. The natural environment, the external pressures for both conservation and deforestation, as well as its human situation make this area an emblem of broader socio-environmental conflicts and an example of a "poverty in paradise" situation (Adams and Hutton 2007; Adams et al. 2004; Peluso 1992; Stonich 1993; Zann and Zann 2008).

Camorcy is situated between the Atlantic Ocean and highway BR-101 (Figure 1). It is in the extreme north of the state of São Paulo, in the municipality of Ubatuba. Camorcy is a village of no more than 150 people, with a large number of children. One of the hallmarks of this community is its relative degree of isolation, even after construction of the highway. At least to the outsider's eye, the community cannot be seen from any point along the road. The only ways to see it are from the ocean, walking along the beach, hiking in the local hills, or by flying over its territory. The core of the community (a few buildings, including two churches) is concealed by a mountainous, steep slope.

The environmental branches of the local and regional governments, directly or indirectly, want to enforce isolation, which is already great due to geography. Officials at the Parque Estadual da Serra do Mar are unwilling to improve access. The park administration has provided no incentive to fix the dirt road (BR101) connecting the community to the "outside world." In its current situation the community is a tourist destination, which requires a landscape impregnated with an outlook of ruralness in harmony with nature. Until 2001, the only way to reach Camorcy from BR-101 was via trails in the forest. In 2003, after years of struggle and a local riot against the Park staff, a dirt road was built to connect to the highway. However, due to steep terrain, and the viscosity of the muddy soil, the road is impassable during the rainy season, which forces the one bus line that transports people in and out of Camorcy to stop short, leaving travelers to walk.

(a)

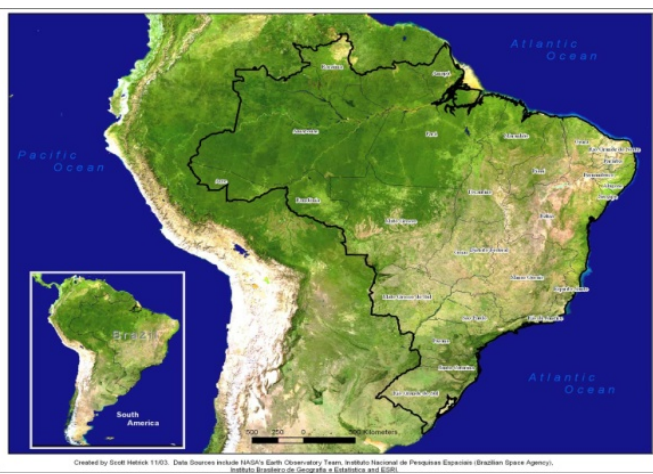

(b)

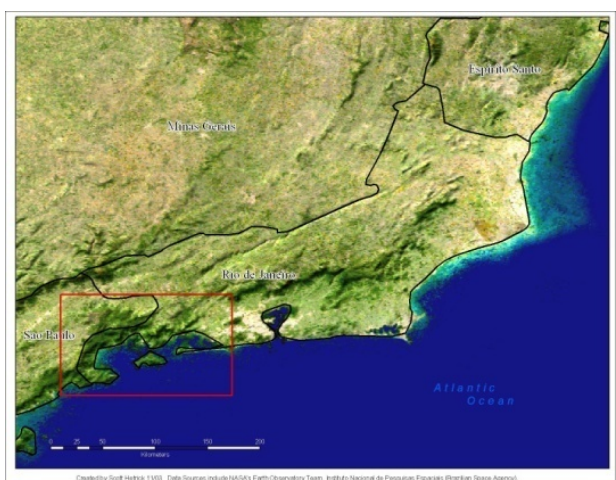

Figure 1: Study site. (a) Brazil, (b) the southeast frontier between the states of São Paulo and Rio de Janeiro. The red box corresponds to the focal region of study, where Camorcy, Caminho das flores, Cabuçu, and other quilombola and caiçara communities are located.

\footnotetext{
4 Instituto Brasil Carbono. Especialistas defendem marco regulatório para o REDD. Accessed April 20, 2013. http://www.institutocarbonobrasil.org.br/reportagens_carbonobrasil/noticia=729959.
} 
Anything that is not low-impact tourism has been banned, and this is enforced by the park staff and the environmental police from São Paulo. This kind of environmental pressure has pushed newcomers, squatters, and extended families (siblings and other relatives) to move uphill, which roughly corresponds to the area claimed by the quilombola association. As a result of many factors, such as distance from the beach (Camorcy's history is rooted in fishing) and the fact that tourists used to come almost exclusively to visit the beach, the uphill areas seem to have become devalued and depreciated over time by most Camorcy inhabitants. This division between the beach and the upland has been expressed through language in a very revealing way, which seems to be radically changing with the formation of the quilombola community. As we will see in more detail, before the formation of a quilombola association in this area (the upland), this patch of land was called a favela (slum) by quilombolas and non-quilombolas. Today, after the 2003 government intervention, the community as a whole is shifting from using the term favela to quilombo.

Camorcy concentrates, in a small geographical area, a wide variety of interest groups and socioenvironmental conflicts. Camorcy and the immediate region surrounding it are a mosaic, or a mirror, of broader society, as well as of global socio-environmental problems. A few kilometers from Camorcy there are industries, nuclear power plants, urban areas, slums, indigenous communities, small farms, other fishing communities, and other quilombos, as well as sites of historical importance and luxury tourist resorts. The community does not have all these assets and landscape features. But despite its size and relative isolation, it retains connections 'outside', including its long history as a regional source of fish and hardwood for a deactivated sawmill that existed until the beginning of the twentieth century. The area exploited by what was apparently a British logging company (according to some elders I interviewed) is now completely covered by secondary vegetation. In brief, Camorcy's trajectory is insightful in that it illustrates how small and powerless groups have been shaped (empowered perhaps) by larger society's demands and policies. Its history and current conflicts also demonstrate how, along with this process of interaction with external actors, communities and individuals transform themselves and mold their own lives according to their own values, traditions, interests, experiences, and opportunities.

\section{The biophysical environment}

Camorcy sits between $23^{\circ} 20^{\prime}$ and $23^{\circ} 25^{\prime}$ south latitude and $44^{\circ} 50^{\prime}$ and $44^{\circ} 48^{\prime}$ west longitude. Three types of tropical ecosystems create an ecological gradient from the ocean to the mountain. From a geomorphological point of view, it forms an amphitheater facing the Atlantic Ocean along a vast region where a narrow coastal plain predominates. The ecological gradient starts at the water line followed by the white-sand beach. In a visible transition, one finds herbaceous vegetation flourishing where salt water still sprays the highly permeable soil without flooding it. Adjacent to this is a gradual change toward a dense vegetation type dominated by shrubs and bushes. The soil is still predominantly sandy, allowing for rapid drainage and low water retention. This is generally referred to as a low sandbank. From there inland, as one moves toward the foothills, taller trees appear, adorned with epiphytes (bromeliads and orchids). This region marks the beginning of what is popularly regarded as the Mata Atlântica, or Atlantic Forest (MMA 2000; Morellato and Haddad 2000; Myers et al. 2000). In places of weak ocean waves and high tides (i.e., jagged bays), at the mouth of the rivers where fresh water encounters salty groundwater, mangroves sprout and form soils with high organic content and low drainage capacity, which leads to the creation of quite distinct phytophysionomy. Moving away from the ocean (upstream) and the mangroves, one approaches the foothills, where the soil becomes deeper and drier with little or no influence of salt.

As one would expect, the ecological profile has been altered over a long history of human occupance. A great portion of it is still very well preserved due to the types of human activities pursued, its low population density, and other factors. Regardless of the relative weight and roles played by geography, park enforcement, the presence of traditional communities, and so on, the positive ecological outcome of these interactions is the main motivation for its current environmental preservation. Many of the fauna and flora in the International Union for Conservation of Nature and Natural Resources (IUCN) Red List of Threatened Species occur in this region. To name just a few animals, one may come across jaguars (Panthera onca), the wooly spider monkey (Brachyteles arachnoides), and the large bird Rufour-vented ground-cuckoo (Neomorphus geoffroyi), usually hunted for food (Environmental Agency of São Paulo1998).

\section{A Brazilian critique of wilderness and conservation ideas in the Atlantic Forest}

Brazil has become part of larger global conservation experiments. This history rapidly unfolded during the military dictatorship from 1964 to 1985 . Influenced by the United States' model of conservation, Camorcy and thousands of other communities were "trapped" into governmentally imposed parks. The creation of parks by the federal and state governments reflects a contradictory view of development that still prevails. While areas considered to be of high conservation priority are set apart as parks, large-scale and development programs are implemented elsewhere (e.g., hydroelectric dams, roads cutting across forest ecosystems). Through the lens of environmental history, I discuss some of the ideas behind the creation of parks in Brazil and deal directly with the intertwined creation of the UNESCO biosphere reserve and the park. 
Several scholars have engaged in unveiling the history of human-environment interactions in the Atlantic Forest biome in Brazil (Dean 1995; Drummond 1997; Oliveira et al. 2011; Pádua 2004). Warren Dean's landmark "With broadax and firebrand: the destruction of the Brazilian Atlantic Forest" (Dean 1995) is the best of its kind. It has inspired an emerging generation of environmental historians in Brazil. Dean's approach toward human-environment relations is one that seeks to find the place of nature in human society. As Rogério Robeiro de Oliveira puts it, environmental historians want to put nature back into social history (personal communication 2003). Dean does not see nature as an objective collection of living beings and goods subjected to human interference, manipulation, usurpation, exploitation, and transformation. Nature, in his view, is a broad set of conditions, which, altered by humans, can lead to the development of almost infinite forms of social life. According to Dean, the first European settlers to arrive in Brazil (predominantly Portuguese) had no appreciation for nature itself. They had a view of it only as an inexhaustible source of materials for the homeland. As a result, for over three centuries, beginning in the 1500s, the vast majority of natural resources extracted from Brazil were shipped directly to Portugal.

The perception of the environment as the source of infinite resources started changing around the midnineteenth century, mainly as the result of water scarcity in emerging cities such as Rio de Janeiro (Pádua 2004). Reconstructing past human-environment interactions through archival research, Dean (1995) proposed that Brazilian intellectuals and abolitionists pioneered the ecological/environmental movement in the Americas even before Yellowstone (the first national park) was implemented in 1872 in the United States. The ecological abolitionists realized that growing urbanization and deforestation were behind the shortage of water. Therefore, in order to restore these resources, a single farmer and a handful of slaves replanted hundreds of native and exotic tree species in the Tijuca Forest in Rio de Janeiro (between 1861 and 1889 ). Later, this area became the National Park of Tijuca, the forest area where the world-renown statue Corcovado (Christ the Redeemer) stands high above sea level.

Despite such pioneering ideas and practices, it was only in 1937 that a national park named Parque Nacional de Itatiaia, the first one of its kind in Brazil, was created. With the advent and diffusion of the parks idea, environmentalists worldwide had an opportunity to apply the idea of wilderness to different contexts (see Cronon 1995 for a more comprehensive history of the wilderness concept in the United States).

Antônio Diegues (1996) was the first Brazilian social scientist to speculate about the positive and negative impacts of applying the American concept of wilderness in Brazil. In his groundbreaking book $O$ mito moderno da natureza intocada ("The modern myth of untouched nature"), he offered sharp criticism toward the unquestioned use in Brazil and neighboring countries of wilderness models (i.e., Yellowstone and Yosemite) or "parks without people." Pioneered a Brazilian environmental sociology approach, he pointed out that the myth of wilderness was at the heart of current socio-environmental conflicts between strict protected areas and other forms of conservation in rural development.

"Wilderness" denotes the idea that nature existed in its pure state until humans arrived. "Nature" is seen as a collection of living beings and inorganic features/materials harmoniously evolving and interacting without human interference. Wilderness supporters have created a new Western myth to describe biomes without markers of human interference, even though considerable archeological, historical, and environmental evidence suggests millennia of human use and management (Balée 1994, 1998; Dean 1995). Putting wilderness protection into practice has perhaps caused more harm to local peoples than it has brought benefits. The UN estimates that around half of the global population (i.e. 3.5 billion people), located mostly in Latin American, Asian, and African countries, base their total or partial livelihoods on direct access to natural resources (i.e., clean water, agricultural lands, wood, charcoal, fisheries, fibers, medicinal plants). Thousands of people living in rural areas have been evicted or have had their livelihoods profoundly altered due to parks and other types of natural reserves (West et al. 2006).

José Augusto Drummond and collaborators (2009) have explored the history and the status of federally protected areas in Brazil. The Brazilian national system of nature-protected areas (SNUC Law of 2001) reflects the long-standing divide between conservation with and without people. The SNUC Law establishes two main groups of protected areas: (1) the areas of indirect use, which correspond to areas strictly protected (e.g., Parque Estadual da Serra do Mar) and (2) the areas of direct use, such as environmental protection areas (APAs) which include mixed uses, various forms of human settlement, and resource use. Although falling within the second category, APAs, which can include whole settlements and urban areas, allow the development of economic activities as defined by specific environmental criteria. In fact, APAs have generally been set up in areas where development initiatives (e.g., roads, airports) are in direct conflict with the purpose of protected areas (Medeiros 2006). The following section illustrates how some of these ideas were implemented in the region and biome where Camorcy is situated.

\section{The UNESCO biosphere reserve and the state park}

Camorcy is situated in the largest remaining forest fragment of the Atlantic Forest in Brazil. Although it is tiny, three large protected areas overlap in its territory. The most important one in terms of influence is the Parque Estadual da Serra do Mar, which I refer to simply as "the park." The other park overlapping a smaller portion of Camorcy is the Parque Nacional da Serra da Bocaina. The national park has a minor effect on the lives of local people in Camorcy because most households are located outside its boundary and their 
economic activities take place outside that area. The national park starts above 100 meters above sea level in steeply sloped terrain. This elevated area, reaching to 400-500 meters within the boundary of the community, is permanently protected by federal law. This means that, regardless of the presence of people, no resources can be extracted. However, the newly recognized quilombo, with the support of Land Institute of São Paulo and the National Institute for Colonization and Agrarian Reform, claim that a large portion of their demarcated territory falls within the area of the national park.

The other major conservation area is the Atlantic Forest Biosphere Reserve. Although this area covers almost all forest remnants of the biome across many states in Brazil, it is hard to grasp the impact of this reserve on the ground. Its indirect impacts are channeled through two main avenues: (1) financing conservation programs (mostly by strengthening environmental law enforcement) and (2) raising awareness and visibility of the region's conservation needs and efforts.

The idea of incorporating people in conservation first appeared (officially) in this region through UNESCO's Man and the Biosphere (MAB) Program, more specifically with the 1991 implementation, at least on paper, of the Atlantic Forest Biosphere Reserve. Biosphere reserves have been set up worldwide with the main objective of reducing socio-environmental conflicts, while reconciling conservation and human development. According to the UNESCO publication titled "The Atlantic Forest Reserve and its applications in the state of São Paulo", there are areas in the world that should be preserved due to their beauty or environmental singularity (Environmental Agency of São Paulo 1998). This document states that these areas are conserved for "all humanity."

In 1968, UNESCO proposed the implementation of a worldwide system of conservation areas. However, it was only in 1971 that the MAB Programme was launched. As of 1998, 330 biosphere reserves in more than 83 countries had been listed. The ultimate goal of these reserves is to create a large-scale, crosscontinental web of nature reserves to preserve global biodiversity, particular forms of resource use, and livelihoods.

All biosphere reserves around the world share the same basic territorial zoning system. The SNUC Law incorporated the same principles. Biosphere reserves should have three main zones or areas. The core zone is the area where the main focus/object of conservation is found, where biodiversity is preserved without direct human interference and where monitoring should be permanent to avoid natural resource degradation. Human settlement is forbidden within this core area. Surrounding the core is the concentric buffer zone, also meant to preserve biodiversity. Human activities are allowed under the rules of the management plan, as long as they are low impact. Here, management of natural resources is permitted under close supervision of trained research and managerial personnel. Resident communities and households are allowed to carry out environmentally friendly economic activities. A package of activities is devised $a$ priori to facilitate the conciliation of development and conservation: ecotourism, environmental education/recreation, and scientific research. The outermost area, surrounding and adjacent to the buffer zone, is the transition zone. The area includes human settlements but is intended to limit activities that pose threats to the environment within the buffer and core zones.

Although the MAB Programme was conceived and implemented in the early 1970s, it was only in the 1990s that the Brazilian Atlantic Forest was internationally recognized as a biosphere reserve. This reserve covers an area of approximately $290,000 \mathrm{~km}^{2}$, stretching across more than 1,000 Brazilian municipalities in 15 states, along 5,000 km of coastline. Although large, the Atlantic Forest corresponds to only a portion of a biome reduced to around 7\% of its original size (SOS Mata Atlântica and INPE 2008). UNESCO incorporated the reserve on its list at the 1992 UN Summit in Rio de Janeiro.

Brazil's Constitution of 1988 changed the Atlantic Forest biome to national patrimony, subject to law enforcement to maintain its protection and rational use. International pressure and local demands from socioenvironmental movements were key driving forces for legal protection of the biome. Deadly landslides and industrial pollution were among the issues that motivated the creation of local environmental groups.

The state of São Paulo pioneered some legal efforts toward forest governance in Brazil. In 1974, the Forest Institute of São Paulo was launched. The following year saw the first scientific assessment of forestcover change for the entire state. The status of the biome was critical, indicating that immediate action had to be taken before it was too late. In 1977, the state once again pioneered efforts by creating the park, covering 315,000 ha (778,000 acres) of mostly dense, closed-canopy tropical forest, plus portions of mangrove forests, swamp forests, sand dunes, and high-altitude grasslands. Later, more protected areas were created, forming what is known as the Atlantic Forest ecological corridor. According to an Environmental Agency of São Paulo document, there are 28 protected areas in the state of São Paulo covering around 3\% (850,000 ha. or 2,100,000 acres) of the territory (Environmental Agency of São Paulo 1998).

The state park where most of Camorcy's territory is situated stretches along the Atlantic coast mountain range, which is the most outstanding geological feature one finds alongside the coastline in southeastern and southern Brazil. In some areas, this chain of mountains touches the ocean. In others, a larger gap between the foothills and the sea creates an ecological gradient enabling the existence of thousands of still unknown fauna and flora. Most of the lowland forest and its associated ecosystems have disappeared. The plateau forest (a drier version of the forest facing the ocean), which used to stretch to the interior and bordered the savannas, has also vanished almost entirely. In the state of São Paulo, key drivers of 
deforestation were the economic cycle of coffee production, from the mid-nineteenth century to the first half of the twentieth century, and intense industrialization subsequently (Dean 1976).

The remaining forest patches have survived due to the high, steep slopes of the mountains. Most of the largest fragments spread beyond 200-300 meters above sea level. The economic exploration of those relatively steep regions has turned out to be too expensive. Therefore, the majority of the protected land within the park is protected by geography. This raises questions regarding the role played by the park in avoiding deforestation.

In 1994, the Environmental Agency of São Paulo renewed a contract for conservation projects with a major donor, the German Development Bank (KfW). This partnership was maintained because the state agency achieved the goal of protecting $10 \%$ of its territory in conservation areas. The sum of US\$ 30 million was used to help consolidate the already established corridor of protected areas that, together, form the Atlantic Forest Biosphere Reserve.

In 1995, the São Paulo government launched PROBIO, the most ambitious research program to investigate multiple aspects of this biome's biodiversity. PROBIO, administered under the auspices of São Paulo's research foundation and environmental agency, was meant to provide tools for the implementation of sustainable economic use of natural resources, as well as the equitable share of benefits, in accordance with the UN Convention on Biological Diversity.

PROBIO has sought to diagnose the status of biodiversity and the challenges for its conservation. Despite the accumulation of an internationally recognized scholarly literature on the bio-ecological process, composition, and structure of the Atlantic Forest ecosystems, it lacks a clear focus on human-environment relations. Biologists and ecologists have done most of the research within the biosphere reserve. Based on archival information I collected in one of the park's operational bases named the Picinguaba core/unit, over $90 \%$ of all research (over two hundred research projects already completed) have dealt exclusively with specific groups of plants and animals. Only around 3\% of the research projects include the local inhabitants' relations to the local environment in their research questions. As a consequence, the scientific knowledge produced has been of limited relevance to inform policies aimed at managing biodiversity, alleviating poverty, and promoting partnerships between local residents and government initiatives.

As expected, the Atlantic Forest Biosphere Reserve's objective of developing environmentally sound economic alternatives within its borders has been poorly implemented. In addition to the emphasis on the ecology of plants and animals, without links to human institutions, economies, cultures, social organizations, and use of natural resources, the safeguard of biodiversity was granted almost exclusively to government environmental agencies. The problem here is that the main environmental agencies lack qualified and experienced staff to simultaneously address human development and conservation issues. Most are trained exclusively in conservation biology, ecology, and environmental sciences. However, it is undeniable that the concept inaugurated within UNESCO's MAB Program has inspired environmentally friendly policies, as well as called attention to the need to address local people's needs in conservation schemes.

In spite of their regulations, today's parks overlap with a variety of local community arrangements, creating new challenges and possibilities for development and conservation. Some of the basic questions to be further explored by looking at the case of Camorcy are: How do these new circumstances facilitate conservation vis-à-vis local development? How do they affect people's livelihoods and the distribution of benefits from the direct and indirect use of natural resources?

\section{Toward building a more collaborative "event ecology"}

In this section, I lay out the approach I have been developing to complement and modify event ecology in this context, inspired by conversations on environmental justice perspectives (Greiber et al. 2009). Drawing on ethnographic data, I try to demonstrate that what is nature conservation for some, may signify oppression, cultural loss, and negative livelihood changes for others. I offer empirical evidence that local people residing in areas affected by nature-protected areas are becoming increasingly aware of the multiple and politically charged meanings that nature and conservation may have for different stakeholders.

According to official and contested definitions, quilombos are communities formed by runaway slaves during and after the slavery period. Since then, it has been estimated that there are around 2.5 million of them scattered across Brazil in approximately 3,500 communities (SEPPIR 2008). In Brazil's Constitution of 1988, these communities were officially recognized as having rights to communal ownership of land, and this has created new forms of struggle for land, including the use of ethnicity as a weapon to gain access to basic resources and to secure fundamental human rights. For most communities, including the case I have been analyzing, the picture gets more complicated because the recognition of ethnic identity and the accompanying phases of land titling are still underway, in areas where strictly protected conservation areas overlap the claimed territories.

Inspired by event ecology, I was initially going to investigate the cumulative effects of a series of historical events defined a priori by me, without consulting with local people. These events were 1) the creation of the park and the construction of BR-101 around 1977, 2) the recognition of the quilombo in Camorcy in 2003, and 3) the arrival of paid electricity in 2007. I wanted to answer whether and how the 
creation of the park in 1977 had been effective in banning agriculture and promoting forest regeneration within this community. I also wanted to understand its effects on people's livelihoods. A more specific question was whether being recognized as quilombolas in 2001, within this strictly protected nature conservation area, had altered local peoples' material livelihoods and their uses of local resources. I hypothesized that quilombolas would become economically better off than non-quilombolas in the short run, despite the long-term risks of freezing their livelihoods in an ethnically defined state of poverty.

After two pre-fieldwork trips to Brazil in the summers of 2006 and 2007, two other questions were incorporated. I started to wonder who decides what would be "good" or "bad" conservation, degradation, and development. I also questioned who benefited most from the intersection of multicultural and environmental policies. In order to address these pressing issues, I realized that some changes to my research approach and design should be made. As I wanted to assess the consequences of events on people and the local environment, I hypothesized that over time the forest cover would increase in association with the progressive banishment of agriculture within the community (forcing people to adopt other economic strategies), as an outcome of law enforcement within the park.

The next section is a brief ethnographic description of how I realized there was something crucial missing in my own framework and methodology. Once in the field, I realized that the events I had chosen should be validated. Thus, I went to test the legitimacy and meaning of my timeline of events against what local people deemed relevant. As we will see, I found that the major events I had chosen (at the regional and community scales) correspond to the major events local people identified and responded to, mainly through changes in livelihoods. While searching for these major events, it became clear that micro-events (at the household level) were also important to explain changes at the community scale.

The modified event ecology methodology I used is in line with Susan Stonich's (2000) approach to political ecology. According to Stonich, the most fundamental factors or tasks needed in order to generate research that can potentially promote effective local community participation are;

(1) identify the major interest groups or stakeholders,

(2) examine the motives and behaviors that affect the use of resources by these groups,

(3) expose actual and potential conflicts among stakeholders, and

(4) identify potential winners and losers as a result of current development and conservation initiatives.

I interviewing local inhabitants of Camorcy about the influences on their community and households over the past 40 years, as part of collecting first-hand and baseline information on livelihoods and environmental change. The general steps I followed while adapting event ecology into a more collaborative methodology were;

(1) identify events based on my own perspectives, questions, and academic training;

(2) through participant observation/interviews, collect data to begin the process of validation (triangulation);

(3) identify, at minimum, what are seen as good and/or bad events to distinct stakeholders (part of the validation process);

(4) move backward in time and outward in space to find the causes of these collaboratively chosen relevant events ${ }^{5}$; and finally

(5) analyze and interpret the implications of identifying these events by applying the rationale of the counterfactual analysis.

The idea behind (5), as proposed by Walters and Vayda (2009), is to simulate future social-ecological outcomes/scenarios should those events not have occurred.

\section{Tourism: performing a quilombola ethnic identity}

In this section I provide ethnographic evidence to further describe recent events that illustrate how a quilombola identity is being constructed in Camorcy vis-à-vis the development of ethnic tourism. I contrast this process with the case of another quilombola community (Caminho das flores) situated in the region of study (Penna-Firme and Brondízio 2007) as well as two other recently recognized quilombola communities in Brazil, Mocambo de Porto da Folha in the state of Sergipe (French 2009) and one in the northern part of the state of Rio de Janeiro (Lifschitz 2008). The analysis highlights important similarities and connections among "independent" processes of legalization of quilombola identities of rural communities in Brazil. The

\footnotetext{
${ }^{5}$ The complementarily of this approach is that in finding out the causes of a given event, the researcher should be able to account for local people's explanations.
} 
comparative analysis also indicates that as local people perform cultural practices associated with an AfroBrazilian heritage, the discourse and outlook of rural poverty of these communities is improved while some aspects of local development remain overshadowed. It indicates the growing role of ethnic identity as a development strategy in rural Brazil. The analysis of this phenomenon also sheds light on the need to further 'open the box' of apparently homogeneous communities and households to illustrate the role of cultural and economic-oriented motivations that drive local people's choices of meaningful events, which are not necessarily captured and fully understood by employing predominantly etic approaches such as event ecology alone, that is, without the aid of ethnographic research.

Since 2003, the Brazilian Ministry of Culture has been running Pontos de Cultura ("Hotspots of Culture"), a large program intended to identify and financially support local cultural initiatives relevant to maintaining cultural diversity in the country. It is a joint venture between the Ministry of Culture and Petrobras, the state-owned Brazilian oil company. As of 2004, the community of Caminho das flores was granted approximately R\$6,000 (about US\$2,900) to initiate a local ethnic tourism project. Although Camorcy has never received financial aid through this government program, the current displays of quilombola ethnic identity in Caminho das flores have directly influenced local and public performances of identity in Camorcy.

This program in Caminho das flores allocated money for teaching young people about their past and their traditions as African slave descendants, done through the development of handicrafts and dance performances. While mostly directed toward education of young people, performances of Afro-Brazilian dances and music such as jongo ${ }^{6}$ represent a major source of pride, an important aspect of the quilombola identity for the entire community as well as a potential source of income associated with ethnic tourism. Examining the process of law making and its impacts on cultural practices, and its transformative effects on culture and identity in northeastern Brazil, Jan Hoffman French (2002, 2006, 2009) argues that the meaning of Mocambo's cultural practice has dramatically changed to comply with the law. ${ }^{7}$ Mocambo residents have "publicly asserted their recently discovered identity as descendants of fugitive slaves, through cultural performances such as processions, plays, and most often, through a dance called samba de coco" (French 2002:19). French explains that "performances of samba de coco have reconfigured for the legal recognition process as evidence of a fugitive slave history, which has become a vehicle both for expressing identity in relation to the law and for addressing deeper yearning for recognition as a delineated community with ties to the land on which its members have lived and worked for generations" (French 2002:20). According to her, "Mocambo residents did not talk about slavery at all before the quilombo clause entered the picture" (French 2006:344).

Caminho das flores leaders have successfully attracted many teenagers to partake in a systematic process of regaining as well as building a quilombola identity through a series of activities, which include but are not limited to jongo. Performances of jongo have been emphasized because it represents African ancestry, enabling participants to embody a rural and quilombola blackness.

As of 2007, during fieldwork in Caminho das flores, I observed the creation of the Jongo do Caminho. From the beginning, the group has been recruiting dancers and performers exclusively among young local residents. Twice a week around 15-20 teenagers gathered to observe, learn, as well as rehearse jongo steps and percussion beats taught by one professional hired by the community through Pontos de Cultura. Similarly, French (2002, 2006, 2009) mentions that during the second anniversary of Mocambo's recognition in 1997, a black activist from the state capital involved in the original decision to pursue the quilombola status gave a workshop in Mocambo on black culture. Lifschitz (2008, 2010) mentions that one NGO contracted by a municipality in northern Rio de Janeiro was hiring dance experts to help form a jongo group, which is already performing in public events and theaters. He argues that the spectacle of the "ethnic difference" and the "anthropological tourism" are becoming widespread across all regions of Brazil, and this involves the reconstruction of ethnic communities involving modern agents through a "mounting" process in which linking local memories and modern devices leads to the formation of "neo-communities."

Jongo has become an important element of quilombolism and blackness beyond Caminho das flores. This community has been able to export itself, its blackness and cultural heritage, and its revitalization and development strategy to other communities in the region as well as across Brazil. In Camorcy, performances of jongo displayed at Caminho das flores have been reappropriated and reshaped to fit local needs to perform "Africanness" for tourists as well as to inspire the formation of a quilombola ethnic identity among its youth. The cultural borrowing from Jongo do Caminho is a remarkable phenomenon led by local Camorcy leaders.

\footnotetext{
${ }^{6}$ Jongo is the precursor or the ancestor of samba, which is one of the most popular music genres of Brazil. Jongo is also a dance performed during a variety of festivities related to the celebration of African heritage and identity, or simply for the pleasure of playing and dancing. Jongo has its origins among slave descendants, who brought African rhythms to Brazil, and is a symbol of resistance and black consciousness that has been considered a vanishing element of the non-material culture of Brazil (cultural patrimony). Therefore, it has been subjected to increasing legal protection and attention from government programs, NGOs, and local communities, where jongo is being revitalized and/or implemented.

${ }^{7}$ Mocambo de Porto da Folha is a village situated on the São Francisco River in the state of Sergipe, Brazil. Mocambo was one of the first quilombola communties to be recognized in Brazil (French 2002, 2006).
} 
In 2009, toward the end of fieldwork, I came across a flyer posted on the wall of a local Camorcy bar. It was an invitation for visitors/tourists to come for the first quilombola festivity in this community. It contained the date and time of the event, logos of the Quilombola Association of Camorcy, and other regional government agencies and NGOs. What intrigued me was the explicit use of the photo of the Jongo do Caminho performing during the Black Conscious Day a few weeks earlier. The same photo was used to advertise the Festa do Azul Marinho (the Blue Fish Festival) at the Cabuçuquilombola community. As we have seen, Camorcy's history lacked jongo and other Afro-Brazilian cultural manifestations prior to these events.

The organizers of the event sought to raise local and outsider awareness of the existence of another quilombo in the region (i.e., Camorcy) while boosting the idea of a commonly shared quilombola identity among camburienses. The festivity was also meant to attract outsiders, visitors, and potential tourism to Camorcy. One of the goals was to raise funds for the quilombola association and a few locals who put on display locally made handcrafts and local quilombola food items, such as grilled corn, boiled manioc roots, and blue fish with rice. On one hand, this event worked as a positive set of sociocultural, psychological, and economic incentives for the development of the quilombola identity and tourism in Camorcy. On the other hand, it illustrates important aspects of the politics of culture and identity building on the ground. More specifically, it shows how identities and symbols of quilombolism and blackness have been blended, reshaped, and reappropriated to revitalize authentic "Africanness" in Caminho das Flores to show the presence of quilombo in Camorcy and elsewhere.

Camorcy is seemingly unique because locals have performed a hybrid traditional population identity, as stewards of nature through demonstrations of sustainable agriculture under community-based management for tourism, and a quilombola identity as authentic African slave descendants through performances of jongo and the display of "typical" quilombola food (Figure 2). However, even in contexts where the purposes of nature conservation are not present, "connecting quilombos to a romantic notion of agricultural practices in Africa creates a special distancing of blackness, relegating it to communities that are different, often through an attempt to document the prevalence of African cultural traits or survival" (French 2006:343).

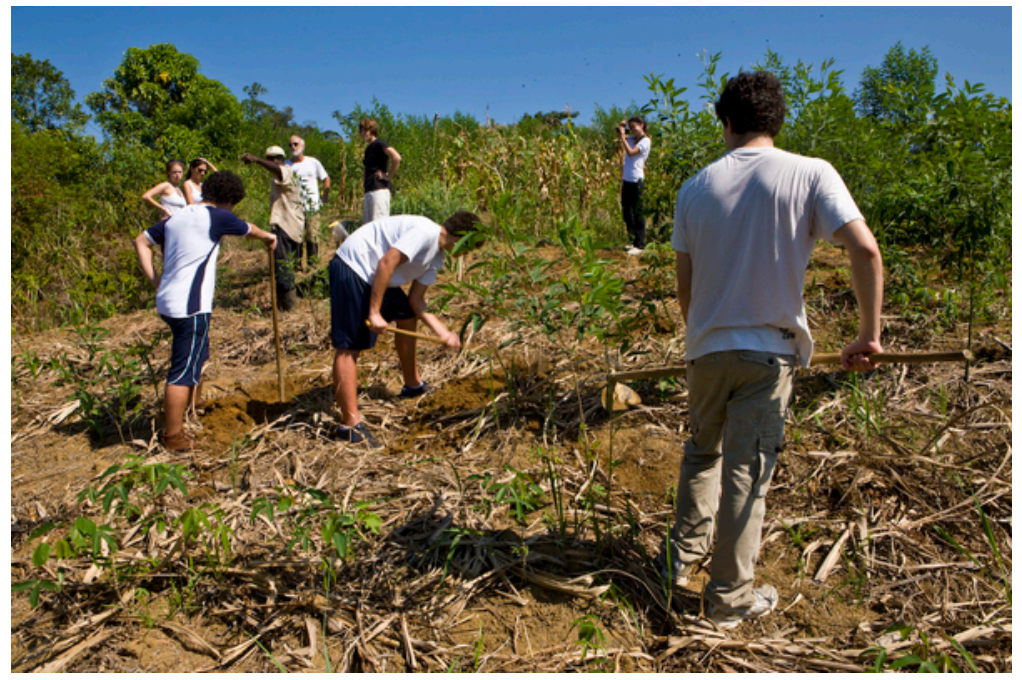

Figure 2: Tourists from São Paulo experiencing and observing demonstrations of quilombola sustainable agriculture in Camorcy (photo by Luiz Frota).

\section{Incorporating local people's perspectives into event ecology}

The local people's own voices represent their concerns and world views through which they interpret events. Even at a small scale, great variations can exist in local perceptions and judgments on what is good and/or bad, and what constitutes conservation or degradation. Ultimately, the data in this article shows how case studies can pinpoint factors tied to people's motivations and perceptions guiding decision-making, including the choice of locally meaningful events.

Besides the macro-events mentioned most often—park, light (electricity), road, and quilombo-locals identified many micro-events such as the death of a husband or the birth of a child. The importance of these events in people's daily lives is rarely taken into account in scientific accounts of socio-environmental change.

Running an analysis of word frequency on the narratives collected through interviews only for events perceived as positive (at the household and community levels) shows a similar order of importance and predominance of terms: light, road, energy, and buses. These four words can be grouped into two categories, 
since they are locally understood as similar. Light and energy mean accesses to electricity, and roads and buses fall into the category of transportation and/or faster access to once-remote places. The two most frequent words used as examples of bad or negative events in order of importance (frequency) were park and quilombo. Although quite revealing, this can be misleading if interpreted in isolation. For instance, in a broader ethnographic context, the high frequency of the word quilombo in the negative events category should not conceal the fact that the quilombola label may bring a series of relative advantages to communities living within strictly protected nature conservation areas. Many interviewees felt the community and households were worse off overall before the government recognition of quilombola status. The occurrence of the word park as negative does reflect what has been happening on the ground, mostly over the past 15 years, since violent environmental law enforcement started in the region.

The most frequent claim, however, was that ever since the park was gazette without local consent, "freedom was lost . . . . I lost my plantation, the right to hunt." One interviewee went on to say that "the community lost its culture because of environmental laws that are squeezing the poor." Another person exclaimed, "One cannot even plant a banana tree .... . If you do, you have to ask for permission that takes ten years to be approved." An elderly woman full of anger and resentment against the park said;

The park only brought misery to this place. There are people here who do not have any small agricultural plot and cannot afford a piece of bread . . . . See what has happened to Trindade Beach. There the people have their things, their money to buy things.

Trindade is a nearby fishing village that has become a crowded tourist destination and where, according to her, the natives decided what to do with their livelihoods, becoming the owners of the tourism business. $^{2}$

Only 3 of 22 interviewees said that nothing positive took place in their households, which might mean one of at least two things; nothing positive really happened, or no event/episode was perceived as bringing improvements to their families' livelihoods despite other evidence. An interesting example is a 51 year-old man who identified no positive change from the park. However, on another occasion when he was asked if the arrival of electricity a year ago had improved his family's life, he responded, "Very much . . . even the household economy. I stopped buying gas cylinders . . . I can read at night . . . information also reaches us by TV and radio to know about Brazil and abroad."

All remaining interviewees reported positive changes to their households/families during interviews. The most frequent word, theme, or event was indeed electricity. The second most important (by the recipients) was the construction of bathrooms in 12 houses sponsored by the government. Six people (selfidentified as quilombolas) saw the quilombo appellation as positive. They highlighted the benefits it had brought. One said that "before it became a quilombo it was harder to talk to people, ... . to have the right to be heard, do agriculture, receive seeds, corn, . . . it is $100 \%$ better today." With the same view, another person commented that because of it there are more "festivities in the community, the feast of cassava, the navy blue fish, like Caminho das flores's party, the Fazenda-da-Caixa's party." One interviewee stressed that "the quilombo brought the paperwork from the Land Institute of São Paulo, strengthening knowledge of the land," and another reiterated "The recognition of the quilombo . . . has loosened up the park's pressure on us."

Some responses stand out, as they speak to the relevance of less obvious economic reasoning. For instance, three local residents said in different ways that "the light was a wonder because I used to spend a lot buying candles, a gas lantern ... . [which] also [posed] a great danger." Another interviewee declared with much relief that he "used to spend over 10 dollars per month on candles; today I only spend around 3 to 4 dollars with a much brighter source of energy." That one shook me, as it reveals the level of economic poverty and low income these people live with. It also provided me with a key understanding of how local peoples' daily lives are deeply affected by these events.

Another interesting local perception of events and changes was the renewed influx of tourists. In the past, before the self-identification of a quilombola community and other traditional peoples living in the area, tourism was merely an activity dominated by middle-class families of southeastern Brazil during weekends and prolonged holidays. As some people put it, now the "the quality of the tourist [is much improved], because before it was only the durista [broke or low economic status tourist] who would come here." Agreeing with recognition of the quilombo, others said, "The tourists would not come up here in the slum." Regardless of this optimism, a number of complaints against the influx of tourists were also reported.

Another relevant side effect of the road construction and the park, according to some residents, was that;

...before we had to walk along the trails, catch boats, it would take almost a week to go from Ubatuba and back here bringing salt and kerosene. Today everything is easier, but with this modernity also came drugs, death, and the violence which I had never seen here.

\footnotetext{
${ }^{8}$ Although it is beyond the scope of this analysis, Trindade has in fact been exploited by unscrupulous tourist developers, who tried to turn it into an international resort while evicting local residents with the use of physical violence.
} 
The road has had positive and negative effects, despite the access it has provided to many people. Some of the negative impacts on livelihoods became clear before starting interviews. One day, when I was heading to the beach talking, I ran into another, 43 year-old fisherman. To keep the conversation going I innocently uttered something about the depth of the river bed, which community members had to cross every day via the bridge. I said, "The river is very full, it must be dangerous to live near it." The immediate response was that "it is nothing compared to what it was." I replied, "How so?" He continued;

Before the road, the river was much deeper. Much of the ravine and dirt created by the process of opening the road went down, clogging the river. . . . Before [that], we would fish tainha and many other fish [to] that mark you see there.

Pointing to a faraway tree marking and remembering when the river was larger and deeper, he said, "When the tide was high, the river rose too, a person would not be standing [in the river] without drowning, but there was plenty of fish, enough to either give away or throw away." The negative side effects of the road were perceived by those who depended directly or indirectly on fishing. These included children's leisure time after school. Around $90 \%$ of all teenage males in this community go fishing at least once a week. ${ }^{9}$

When talking with administrators and employees of the park and other organizations or when observing in their offices and meetings, I never contested anything I saw and heard. I never asked directly any NGO staff or park officials what they understood as 'events'. Having access to emails, documents, and participating in some of their internal discussions allowed me to grasp what mattered for the purpose of achieving conservation goals. The quilombo recognition represents a major backlash to conservation efforts, or at least an enormous risk that the environmental side of the government is not willing to take. That is, in the eyes of the park staff, the quilombo recognition was a major negative event. This was disguised and concealed in interactions with local people.

One of the major sources of discontent among locals is that they know the park designation implies the abandonment of their use of fire for clearing. They are also aware that many of their staple crops such as manioc and beans will not grow under the shadow of mature trees. This is unnoticed by NGOs' agroforestry experts.

The conversion of a few, abandoned, old agricultural areas into agroforestry was never mentioned by local people as a major event. But it was a desire of the government for conservation of forest resources in the community and adjacent areas. One reason for local indifference was that most agricultural fields had already been eliminated by park enforcement. There are only a handful of adults (and virtually no young people) still engaged in agriculture. The prohibition of farming has eliminated an entire intergenerational familiarity with agriculture, while paradoxically removing a traditional activity from a traditional population.

\section{Tradeoffs between "modernity" and "tradition"}

Since the end of the 1980s and the beginning of the 1990s, multicultural and conservation policies that promote the image of rural groups as 'stewards of nature' and granted titles to communal territories have surfaced in countries including Brazil (Castro et al. 2006; French 2009; Little 2002; Penna-Firme and Brondízio 2007), Belize (Holmes 2010), Colombia (Escobar and Paulson 2005), Ecuador (Sánchez 2008), Peru (Van den Berghe and Flores-Ochoa 2000), and Honduras (Anderson 2007). The case of Camorcy illustrates the impacts of these policies in Brazil, and the problem of reconciling people within protected areas. The study suggests that legally recognized ethnic identity may promote local-level conflicts and divisions even within small communities, potentially reinforcing an already-skewed distribution of benefits among these groups. For groups such as caiçaras, who are invisible in legal frameworks, multicultural and reparation policies will have little effect in terms of new development opportunities.

On one hand, such multicultural policies tend to overemphasize socio-cultural differences, while overlooking some of the socio-economic similarities and common agendas of groups that are allegedly distinct. They might be promoting cultural diversity where there is very little. The major risk, however, is that while empowering local groups, multicultural recognition may also essentialize traditional communities and perhaps further crystalize people's cultural and economic identities. On the other hand, ethnicity has become a major development alternative for the rural poor and the unassisted to secure land rights, and to access education, health, transportation, and citizenship more broadly. In neoliberal times, "going ethnic" seems to be progressively replacing class-based claims that once attempted to challenge the pillars and functioning of capitalism and socio-environmental injustice. Perhaps rural groups that are officially turned into traditional communities will stand a better chance of securing rights as "ethnic citizens" (Holmes 2010), despite unknown tradeoffs and future outcomes. So far, in Camorcy, this trend has favored quilombolas.

\footnotetext{
${ }^{9}$ Based on personal observation over 10 months.
} 


\section{Final remarks}

Stakeholders' perceptions of events in my study indicate that (1) local people tend to identify with and talk about events they have witnessed and personally experienced, especially when outcomes alter their livelihoods; (2) most events considered good or bad for local people were imposed upon them by exogenous forces, such as conservation policies and the arrival of electricity; (3) conservation that is thought of as good by one person might be considered by others as contributing to a lack of freedom, choice, opportunity, work, food on the table, or pride, and therefore be understood as a negative event; and (4) an array of events other than those linked to environmental change are identified by local people.

Broader lessons can be drawn from the evidence. Seeing 'events' other than research-oriented ones may help us better understand why some places achieve conservation while others do not. If one does not take into account the perceptions and experiences of the people who carry the burden of deforestation and/or conservation, research results may be more compliant with dehumanized assessments of human-environment relations. Assessing conservation effectiveness only by means of environmental outcomes risks being socially unjust in the eyes of local people, while posing a real threat to local livelihoods and communitybased development expectations. The general methodological steps presented in this article are an explicit attempt to integrate attention to macro- and micro-events and, in the process, to build a more collaborative 'event ecology.' Collaborative event ecology may perform the dual task of exploring the historical environmental changes and their causes as well as assessing the local-level social impacts and meanings of conservation and degradation for diverse stakeholders. I also hope to advance the formulation of research methodologies that shed light on the interrelation of multicultural, development, and conservation policies and their effects on human-environment relations. Scholarly works on the commons have shown that resource users, whose expected behavior will be not to comply with exogenously imposed rules of resource use and access (e.g., Ostrom 2007), rarely legitimize methodologies and decisions regarding the use and access of natural resources without local participation. Therefore, a collaborative methodology should include multiple stakeholders' understandings of what is perceived as good and bad, and for whom.

\section{References}

Adams, W.M. and J. Hutton. 2007. People, parks and poverty: political ecology and biodiversity conservation. Conservation and Society 5(2): 147-183.

Adams, W.M., R. Aveling, D. Brockington, B. Dickson, J. Elliott, J. Hutton, D. Roe, B. Vira and W. Wolmer. 2004. Biodiversity conservation and the eradication of poverty. Science 306(2): 1146-1149.

Alvarez, S., E. Dagino and A. Escobar (eds.). 1998. Cultures of politics, politics of culture: re-visioning Latin American social movements. Boulder, CO: Westview.

Anderson, M. 2007. When Afro becomes (like) indigenous: Garifuna and Afro-indigenous politics in Honduras. Journal of Latin American and Caribbean Anthropology 12(2): 384-413.

Balée, W. 1994. Footprints of the forest: Ka'apor ethnobotany - the historical ecology of plant utilization by an Amazonian people. New York: Columbia University Press.

Balée, William (ed.) 1998. Advances in historical ecology. New York: Columbia University Press.

Brondízio, E.S. 2008. The Amazonian caboclo and the açaí palm: forest farmers in the global market. Advances in Economic Botany Monograph Series, Vol. 16. New York: New York Botanical Garden Press.

Castro, F. de, A.D. Siqueira, E.S. Brondízio and L.C. Ferreira. 2006. Use and misuse of the concepts of tradition and property rights in the conservation of natural resources in the Atlantic Forest (Brazil). Ambiente e Sociedade 19(1): 24-41.

Cronon, W. 1995. Uncommon ground: towards reinventing nature. New York: Norton.

Dean, W. 1976. Rio Claro: a Brazilian plantation system, 1820-1920. Stanford, CA: Stanford University Press.

Dean, W. 1995. With broadax and firebrand: the destruction of the Brazilian Atlantic Forest. Berkeley: University of California Press.

Diegues, A. 1996. O mito moderno da natureza intocada. São Paulo, Brazil: Hicitec.

Drummond, J.A. 1997. Devastação e preservação ambiental: os parques nacionais do Rio de Janeiro. Niterói: UDUFF.

Drummond, J.A., J.L. de Andrade Franco and A. Bortoni Ninis. 2009. Brazilian federal conservation units: a historical overview of their creation and of their current status. Environment and History 15: 463-491.

Environmental Agency of São Paulo. 1998. A Reserva da Biosfera da Mata Atlântica e sua aplicação no Estado de São Paulo. São Paulo, Brazil: Terra Virgem.

Escobar, A. and S. Paulson. 2005. The emergence of collective ethnic identities and alternative political ecologies in the Colombian Pacific rainforest. In S. Paulson and L.L. Gezon (eds.) Political ecology across spaces, scales, and social groups. Piscataway, NJ: Rutgers University Press. Pp. 257-279. 
French, J.H. 2002. Dancing for land: law making and cultural performance in northeastern Brazil. Political and Anthropology Review 25(1): 19-36.

French, J.H. 2006. Buried alive: imagining Africa in the Brazilian northeast. American Ethnologist 33(3): 340-360.

French, J.H. 2009. Legalizing identities: becoming Black or Indian in Brazil's northeast. Chapel Hill: University of North Carolina Press.

Gomes, F. 2003. Quilombos: sonhando com a terra, construindo a cidadania. In F. Gomes (ed.) História da Cidadania. São Paulo, Brazil: Contexto. Pp. 446-467.

Greiber, T., M. Janki, M. Orellana, A. Savaresi and D. Shelton. 2009. Conservation with justice: a rightsbased approach. IUCN environmental law and policy paper no. 71. Gland, Switzerland: International Union for Conservation of Nature.

Hoekema, A. and W. Assies. 2000. Managing resources: between autonomy and partnership. In W. Assies and A. Hoekema (eds.) The challenge of diversity: indigenous peoples and reform of the state in Latin America. Amsterdam: Thela Thesis. Pp. 245-260.

Holmes, T. 2010. Tourism and the making of ethnic citzenship in Belize. In D.V.L. Macleod and J.G. Carrier (eds.) Tourism, power and culture: anthropological insights. Exeter, U.K.: Short Run Press. Pp. 153168.

Lees, S. and D. Bates. 1990. The ecology of cumulative change. In E.F. Moran (ed.) The ecosystem approach in anthropology. Ann Arbor: University of Michigan Press. Pp. 247-277.

Lifschitz, J.A. 2008. Percursos de uma neocomunidade quilombola: entre a "modernidade" Afro e a "tradição" Pentecostal. Afro-Ásia 37: 153-173.

Lifschitz, J.A. 2010. Comunidades étnicas no Brasil e modernização. Avá 18: 11-24.

Little, P. 1999. Environments and environmentalism in anthropological research: facing a new millennium. Annual Review of Anthropology 28: 253-284.

Little, P. 2002. Territórios sociais e povos tradicionais no Brasil: por uma antropologia da territorialidade. Série antropologia, no. 322. Brasilia, Brazil: Universidade de Brasília, Departamento de Antropologia.

Medeiros, R. 2006. Evolução das tipologias e categorias de áreas protegidas no Brasil. Ambiente \& Sociedade 9(1): 41-64.

MMA (Ministério do Meio Ambiente). 2000. Avaliação e ações prioritárias para a conservação da biodiversidade da Mata Atlântica e Campos Sulinos. Brasilia, Brazil: MMA e dos Recursos Naturais Renováveis.

Moran, E.F. 1990. Levels of analysis and analytical level shifting: examples from Amazonian ecosystem research. In E.F. Moran (ed.) The ecosystem approach in anthropology: from concept to practice. Ann Arbor: University of Michigan Press. Pp. 279-319.

Morellato, L.P.C. and C.F.B. Haddad. 2000. Introduction: the Brazilian Atlantic Forest. Biotropica 32(4b): 786-792.

Myers, N., R.A. Mittermeier, C.G. Mittermeier, G.A.B. da Fonseca and J. Kent. 2000. Biodiversity hotspots for conservation priorities. Nature 403: 853-858.

Offen, K. 2003. The territorial turn: making black territories in Pacific Colombia. Journal of Latin American Geography 2(1): 43-73.

Oliveira, R.R. de, J.S. Fraga and D.E. Berck. 2011. Uma floresta de vestígios: metabolism social e a atividade de carvoeiros nos séculos XIX e XX no Rio de Janeiro. Interthesis 8(2): 286-315.

Ostrom, E. 2007. A diagnostic approach for going beyond panaceas. Proceedings of the National Academies of Science of the United States of America 104(39): 15181-15187.

Pádua, J.A. 2004. Um sopro de destruição: pensamento político e crítica ambiental no Brasil escravista 1786 /1888, Rio de Janeiro. Rio de Janeiro: Jorge Zahar Editor.

Peluso, N. 1992. Rich forests, poor people. Berkeley: University of California Press.

Penna-Firme, R. and E. Brondízio. 2007. The risks of commodifying poverty: rural communities, quilombola identity and nature conservation in Brazil. Habitus 5(2): 355-375.

Redford, K. 1990. The ecologically noble savage. Cultural Survival Quarterly 15(1): 46-48.

Robbins, P. 2003a. Beyond ground truth: GIS and the environmental knowledge of herders, professional foresters, and other traditional communities. Human Ecology 31(1): 233-254.

Robbins, P. 2003b. Fixed categories in a portable landscape: the causes and consequences of land cover categorization. In K.S. Zimmerer and T.J. Bassett (eds.) Political ecology: an integrative approach to geography and environment-development studies. New York: The Guilford Press. Pp. 181-200.

Robbins, P. 2004. Political ecology: a critical introduction. Malden, MA: Blackwell.

Sánchez, J.A. 2008. Multiethnic nations and cultural citizenship: proposals from the Afro-descendant movement in Ecuador. Souls 10(3): 215-226. 
SEPPIR (Secretaria de Políticas de Promoção da Igualdade Racial). 2008. Programa Brasil Quilombola: comunidades quilombolas Brasileiras: regulação fundiária e políticas públicas. Brasilia, Brasil: SEPPIR.

SOS Mata Atlântica and INPE (Fundação SOS Mata Atlântica and Instituto Nacional de Pesquisas Espaciais). 2008. Atlas dos remanescentes florestais da Mata Atlântica: período 2000-2005. São Paulo, Brazil: SOS Mata Atlântica.

Stern, P.C., T. Dietz, N. Dolšak, E. Ostrom and S. Stonich. 2002. Knowledge and questions after 15 years of research. In E. Ostrom, T. Dietz, N. Dolšak, P.C. Stern, S. Stonich and E.U. Weber (eds.) The drama of the commons. Washington, DC: National Academies Press. Pp. 445-489.

Stonich, S. 1993. "I am destroying the land!": the political ecology of poverty and environmental destruction in Honduras. Boulder, CO: Westview Press.

Stonich, S. 2000. The other side of paradise: tourism, conservation and development in the Bay Islands. New York: Cognizant Communication Corp.

Van den Berghe, P.L. and J. Flores-Ochoa. 2000. Tourism and nativistic ideology in Cuzco, Peru. Annals of Tourism Research 27(1): 7-26.

Vayda, A. 1983. Progressive contextualization: methods for research in human ecology. Human Ecology 11: 265-281.

Vayda, A. and B. Walters. 1999. Against political ecology. Human Ecology 27: 167-179.

Wade, P. 1995. The cultural politics of blackness in Colombia. American Ethnologist 22(2): 341-357.

Walters, B. and A. Vayda. 2009. Event ecology, causal historical analysis and human environment research. Annals of the Association of American Geographers 99(3): 534-553.

West, P., J. Igoe and D. Brockington. 2006. Parks and peoples: the social impact of protected areas. Annual Review of Anthropology 35: 251-277.

Zann, S. and L. Zann. 2008. Poverty in paradise? Issues in poverty and development in Fijian fishing villages. SPC Women in Fisheries Information Bulletin 18: 36-41.

Zimmerer, K. (ed.) 2006. Globalization and new geographies of conservation. Chicago, IL: University of Chicago Press. 


\begin{abstract}
The field of political ecology has striven to balance a focus on symbolic and materialist aspects of humanenvironment relations. Event ecology has emerged not only as a major materialistic approach for the study of human-environmental relations, but also as an important set of critiques of political ecology's supposed lack of ecology and overreliance on a priori assumptions about the linkages between local environmental changes and macropolitical economic phenomena. This article discusses the origins and progress of event ecology, while demonstrating its strengths and limitations vis-à-vis the development of political ecology research. Based on participant observation and interviews conducted among local residents of a small village (a quilombola community) in a state park in São Paulo, Brazil, I propose a collaborative event ecology that combines the rationale of event ecology with critical perspectives inspired by political ecology's focus on power relations, conservation and justice. Unlike the strict application of event ecology, I contend that scrutinizing events other than researcher-oriented ones may help us better understand why some places achieve conservation while others do not. The article concludes that assessing conservation effectiveness and change through environmental outcomes alone risks being seen as socially unjust in the eyes of locals while posing a real threat to local livelihoods and community-based development expectations.
\end{abstract}

Key words: collaborative event ecology, conservation with justice, quilombola communities, Atlantic Forest, Brazil.

\title{
Résumé
}

Le champ de l'écologie politique s'est efforcé d'équilibrer l'accent sur les aspects symboliques et matérialiste des relations homme-environnement. Écologie événement (event ecology) a émergé non seulement comme une approche matérialiste majeur pour l'étude des relations homme-environnement, mais it est aussi un important ensemble de critiques de la prétendue absence de de l'écologie en l'écologie politique, et un dépendance excessive sur les hypothèses a priori sur les liens entre les changements environnementaux locaux et des phénomènes économiques macropolitiques. Cet article décrit les origines et les progrès de l'écologie de l'événement, tout en démontrant ses forces et ses limites vis-à-vis du développement de la recherche en écologie politique. Basé sur l'observation participante et entretiens réalisés auprès des résidents locaux d'un petit village (une communauté quilombola) dans un parc national de São Paulo, au Brésil, je propose une écologie de l'événement collaborative, qui combine la logique de l'écologie de l'événement avec des perspectives critiques inspirées par l'accent mis par l'écologie politique sur les relations de pouvoir, de la conservation et de la justice. Contrairement à l'application stricte de l'écologie de l'événement, je soutiens que scruter d'autres événements que ceux qui axées sur chercheur, peut nous aider à mieux comprendre pourquoi certains endroits assurer la conservation tandis que d'autres ne le font pas. L'article conclut que l'évaluation de l'efficacité de la conservation et du changement à travers les résultats environnementaux seuls, risques étant considérés comme socialement injuste aux yeux de la population locale tout en posant une réelle menace pour les moyens d'existence locaux et les attentes de développement communautaires.

Mots clés: écologie de l'événement collaborative, la conservation et la justice, les communautés quilombolas, la Forêt Atlantique au Brésil.

\section{Resumen}

La ecología política ha procurado balancear los aspectos simbólicos y materiales de las relaciones entre el medio ambiente y los humanos. La ecología de eventos ha surgido no sólo como un acercamiento principalmente material para el estudio de las relaciones humano-medio ambiente, pero también como una crítica importante a la supuesta falta de ecología en la ecología política, y una llamada para reconocer supuestos a priori sobre las conexiones entre cambios en los medios ambientes locales y fenómenos macropolíticos y -económicos. Este artículo discute el origen y el desarrollo de la ecología de eventos al mismo tiempo que demuestra sus fortalezas y limites comparándolo con el desarrollo de la ecología política. Basado en observación participativa y entrevistas realizadas entre habitantes de una pequeña aldea (comunidad quilombola) ubicada en el parque estatal de São Paulo, Brasil, propongo una ecología de eventos colaborativa que combina la racionalidad de la ecología de evento con las perspectivas críticas inspiradas por el énfasis de la ecología política en las relaciones de poder y la conservación con justicia. Contrario a la ecología de evento estricta, yo propongo que al ver otros eventos aparte de los que están orientados a la investigación nos ayuda a entender las razones porque algunos lugares logran la conservación y otros no. El artículo llega a la conclusión que la evaluación de la eficacia de la conservación y el cambio a través de los resultados ambientales solos, los riesgos que se consideran injustas a los ojos de los habitantes locales, mientras que presenta una amenaza real para los medios de vida locales y las expectativas de desarrollo de la comunidad.

Palabras clave: Ecologia de eventos; ecología política; quilombola, conservación. 